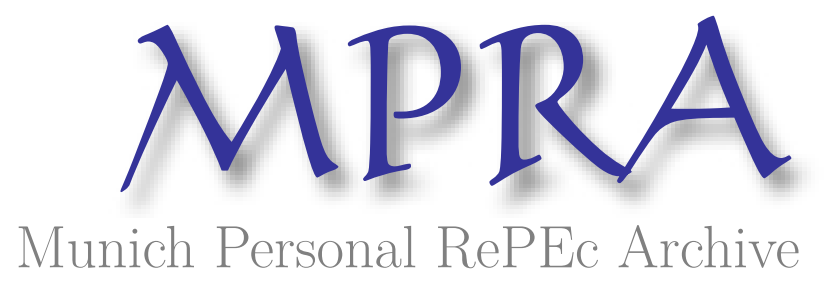

\title{
Impact of external factors That Affecting Operational Risk of Logistic Company in North America
}

jiang, zhenghong

20 May 2018

Online at https://mpra.ub.uni-muenchen.de/86856/

MPRA Paper No. 86856, posted 21 May 2018 09:58 UTC 
Impact of external factors That Affecting Operational Risk of Logistic Company in North America

Jiang Zhenghong

\author{
Universiti Utara Malaysia
}




\begin{abstract}
In this paper I attempt to investigate impact of external factors that affecting operational risk of logistic company in North America which is Expeditors International of Washington. This study was carried out using the secondary data which was obtained from the annual reports of three companies in consecutive years from 2012 until 2016. Inflation rate has been as the dependent variable to study its relationship with the independent variables such as Return on Equity (ROE), Return On Asset (ROA) and other risk factor variables.
\end{abstract}

Keywords: inflation, Return on Equity (ROE), Return On Asset (ROA), operational risk

\title{
1.0 INTRODUCTION
}

\section{Background of Industry}

The U.S. express delivery industry has entered a mature period, with current business volume of approximately 12 billion units and revenue of approximately US\$132 billion, which is 3 times and 11 times that of China respectively. The domestic business formed a stable duopoly: the market share of UPS and FedEx in the land transport market was 51\% and 19\% respectively, and the airfreight market was $35 \%$ and $40 \%$ respectively; while in the international business, the combined market share of the two giants exceeded half . U.S. express companies provide highly differentiated services based on timeliness and weight, and differentiate pricing accordingly. Express prices for the same weight and distance are almost 2 to 3 times that of China. With the oligopolistic structure becoming more stable, differentiated services, and improved technical and operational levels, from 1992 to 2008, FedEx's single-item prices have risen by nearly 50\%, and operating margin improved by 7 percentage points to $9 \%$. 


\section{Background of Company}

Expeditors International of Washington, Inc. provides logistics services in the Americas, North Asia, South Asia, Europe, the Middle East, Africa, and India. The company offers airfreight services, such as air freight consolidation and forwarding; ocean freight and ocean services, such as ocean freight consolidation, direct ocean forwarding, and order management; customs brokerage, intra-continental ground transportation and delivery, and warehousing and distribution services; and customs clearance, purchase order management, vendor consolidation, time-definite transportation services, cargo insurance, cargo monitoring and tracking, and other logistics solutions. It acts as a freight consolidator or as an agent for the airline, which carries the shipment. The company also provides ancillary services that include preparation of shipping and customs documentation, packing, crating, insurance services, negotiation of letters of credit, and the preparation of documentation to comply with local export laws. Its customers include retailing and wholesaling, electronics, and industrial and manufacturing companies. Expeditors International of Washington, Inc. was founded in 1979 and is headquartered in Seattle, Washington.

\section{Product and Services}

Washington's Expeditors International provides logistics services in the United States and internationally. The company's services include consolidation or trans-shipment of air and sea freight; distribution management; supplier consolidation; cargo insurance; purchase order management; and customized logistics information.

\section{Risk and Performances}

Risk is a kind of uncertainty, it will bring results, whether it has a negative or positive impact on organizational performance and strategy. Organizational strategy researchers have demonstrated that business risks affect organizational strategy and performance. Risks not only affect the company's internal factors (such as stakeholders, creditors, customers) in many ways, but also external factors can be affected by economic performance, inflation, and price changes beyond the control of the company. The most critical step in the organization is to identify the risks or threats that may affect the company's goals before proceeding with further steps. 
External factors may be the cause of the company's performance. For example, external factors that influence the company's investment decisions. Changes in economic factors such as GDP, inflation, prices, and government regulation will affect the company's investment decisions or investment or no investment. Lack of market knowledge and lack of investment experience can lead companies to make wrong decisions. Internal factors may also be the cause of the company's performance, such as liquidity.

\subsection{LITERATURE REVIEW}

Washington's Expeditors International provides a full suite of global logistics services, providing customers with an integrated global network of personnel and integrated information systems to support the movement and strategic positioning of cargo. As a third-party logistics provider,

purchases cargo space from operators (including airlines and shipping companies) on a batch basis and resells this space to its customers.

The company offers a wide range of customer solutions such as order management, scheduled transportation, warehousing and distribution, temperature controlled transport, cargo insurance, professional cargo monitoring and tracking, and other custom logistics solutions.

Expeditors' main services include:

Air Freight Service

Shipping and shipping services

Customs brokers and other services

Air Freight Service

Air freight services accounted for $42 \%, 40 \%$ and $41 \%$ of Expeditors' total revenue and $32 \%$, $32 \%$ and $34 \%$ of total net income in 2017, 2016 and 2015, respectively. When performing air freight services, EXPD usually acts as a freight consolidator or as an airline agent of the goods being carried. As a freight consolidator, the company purchases cargo space from the airline on a bulk basis and resells the space to the customer at a lower price than the airline directly on the individual shipment. Whether as a consolidator or an agent, EXPD provides expertise to achieve optimal transportation routes, is familiar with local business practices, understands import and 
export documents and procedures, arranges ancillary services capabilities, and provides assistance in providing space availability during periods of high demand.

As a freight forwarder, Washington Expeditors International has purchased bulk air and sea freight space, and resold the space to customers at a speed lower than that obtained directly from the operator. The company also acts as a customs broker for air and sea freight forwarded by customers and provides supply chain management services. Clients include global businesses engaged in retail/wholesale, electronics and manufacturing.

Companies in this industry provide freight forwarding and customs services. Major companies include CH Robinson Worldwide, Washington Expeditors International and UPS Supply Chain Solutions (all located in the United States) and CEVA Logistics (France); DB Schenker and DHL Supply Chain (Germany); Kuehne + Nagel and Panalpina (Switzerland); Japan Express ( Japan); and Sinotrans (China).

\section{Competitive landscape}

Demand is driven by the level of domestic manufacturing output and international trade. The profitability of individual companies depends on efficient operations, extensive relationships between shippers and operator networks, and industry expertise. Big companies have advantages in account relationships and access to advanced logistics technologies. Small businesses can effectively compete by serving the local market, specializing in the transfer of goods with specific countries, and promoting the transport of unusual goods. The U.S. industry is decentralized: the top 50 companies account for about one-third of their revenue.

\section{Products, Operations and Technology}

Unlike a fully integrated transport company that owns trucks, railroads, air or maritime assets, and transport goods, freight forwarders do not need to own any transport equipment or process ("fingerprint") goods to arrange for the transport of goods. Customs brokers have added another layer of expertise by facilitating the clearance of goods through international customs barriers. Most companies specialize in freight forwarding operations or agency customs clearance services, although some offer both types of business. 


\subsection{RESEARCH METHODOLOGY}

The nature of this research is retrospective. This study employs multivariate examination to measure the significant influence the specific and macroeconomic variables on profitability of Logistics company Company.

\section{Data and Sampling}

The sample used in this study comprises 5 years annual report which operating from expeditors international of washington. Data were extracted from the annual report financial statements of the samples companies from the year 2011 to 2017.

\section{Variables}

This study used expeditors international of washington's specific variables and certain macroeconomic variables. The dependent variable in the study is company profitability which measured here by the Return on Asset (ROA) and defines:

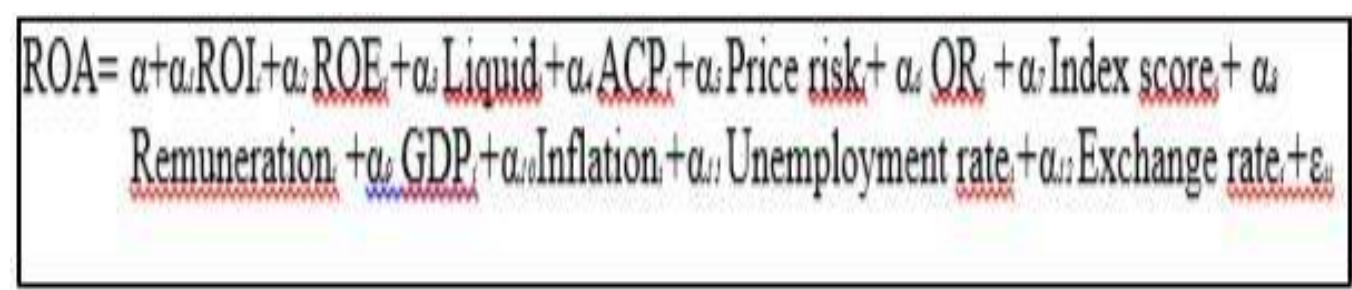

For the independent variables which influenced the company profitability which Return on Investment, Operating Ratio, Average Collection Period.However, there is some external factor also impacted the profitability of the company which is inflation rate, unemployment rate, exchange rate and GDP. Regression analysis and correlation used to show the relationship between the profitability and specific and macroeconomic variables. 
Data was analyzed by using regression and correlation. The model is used to study the risk and performance of expeditors international of washington based on the following equation:

\subsection{DESCRIPTIVE ANALYSIS}

4.1 Return on Asset

Figure 1: Return on Asset

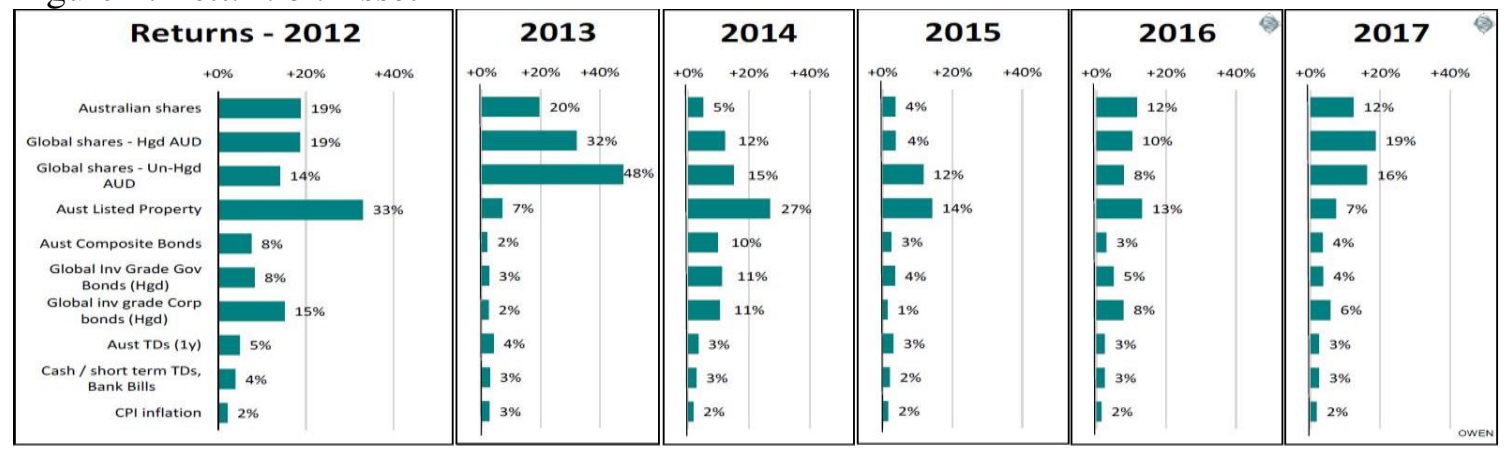

Compared with other companies, ROA of 2011 Expeditors International of Washington is the highest ROA. Typically, return on assets represents the ability of the company to generate based on the number of assets it owns. In other words, it shows potential investors the amount that management can use to generate the assets it owns. Senior companies have higher return on assets. In addition, higher returns on assets tell potential investors that the management of Expeditors International of Washington is using its assets more effectively to finance. However, there are certain internal factors that affect the company's ROA, such as the size of the company (total assets). Although Expeditors International of Washington had the smallest scale (total assets) of $1,161,464,000$ dollars in 2011 , it shows that the company can create higher profits by effectively utilizing the company's assets. The higher return on assets shows that the company can increase its ability to provide compensation to employees. Investors often see the company's ROA because ROA can quickly show whether the company continues to earn more and more profits for every dollar of investment. Investors always expect that good management will try to increase 
4.2 ROA and it have been proven in Expeditors International of Washington.

In addition, external factors also have an impact on ROA. For example, if there is any increase in GDP, it has a positive effect on ROA. Therefore, the growth of GDP led to the increase of the company's ROA. However, good corporate governance will also increase the company's ROA. There are several factors in corporate governance, such as the presence of female board members, the work experience of board members, and the remuneration of board members that have a positive effect on business performance, measured in return on assets (ROA). For example, the higher the average age of most board members, the more experience they have compared to the average number of young people. If the board member has more experience, it can expect to make a positive contribution to the company's performance and will lead to a higher ROA. However, in 2015, Expeditors International of Washington showed a minimum and negative ROA of -0.1577 .

\section{3 -4.4 Return on Equity}

Figures $2 \mathrm{a}$ and $2 \mathrm{~b}$ show the Return on Equity (ROE) information for Expeditors International of Washington between 2012 and 2017. Before conducting a general trend analysis of the above ROE Negative equity returns show that companies are inefficient in using company assets to generate profits. Liquidity risk is a factor that affects a company's ROA. If the company has a large amount of assets, it

means that the company is financially very controlled. At the same time, if the company suffers any financial burden, the company can quickly convert the assets into cash. The same is true of Expeditors International of Washington, whose ROA declined in 2016 because of the company's minimal assets. Therefore, if the company has any financial issues, it is difficult for the company to convert its minimum assets into cash.

Therefore, it can be concluded that ROA is mainly influenced by internal and external factors of the company. In short, Expeditors International of Washington is a company that investors typically invest in because Expeditors International of Washington's high return on assets means that the company is more efficient at making money on assets. 
After review, the formula for calculating the ratio for 2012-2017 is as follows: Return on equity (ROE): Net income / shareholders' equity

\section{Return on equity}

Figure 2a: Return on equity

Return on equity (ROE) is used to measure how effectively companies use shareholders' funds to obtain profits and develop companies. Expeditors International of Washington's 2015 ROE is the highest $\mathrm{ROE}$, with a ratio of 0.8915 . The higher the ratio, the more effective it is to use stockbased management, and the higher the investor's return. The ROE ratio commonly used by investors is an important tool for measuring the performance of a company's earnings. The ROE of Expeditors International of Washington told ordinary shareholders in 2012 how their funds were used effectively. In other words, the return on equity shows the profit per dollar generated by the ordinary shareholders' equity. Each time it invests 1 shareholder's funds into the company, it can generate 0.89 of revenue. This is a critical measure for potential investors, because usually they will see how companies use their funds to earn net income.

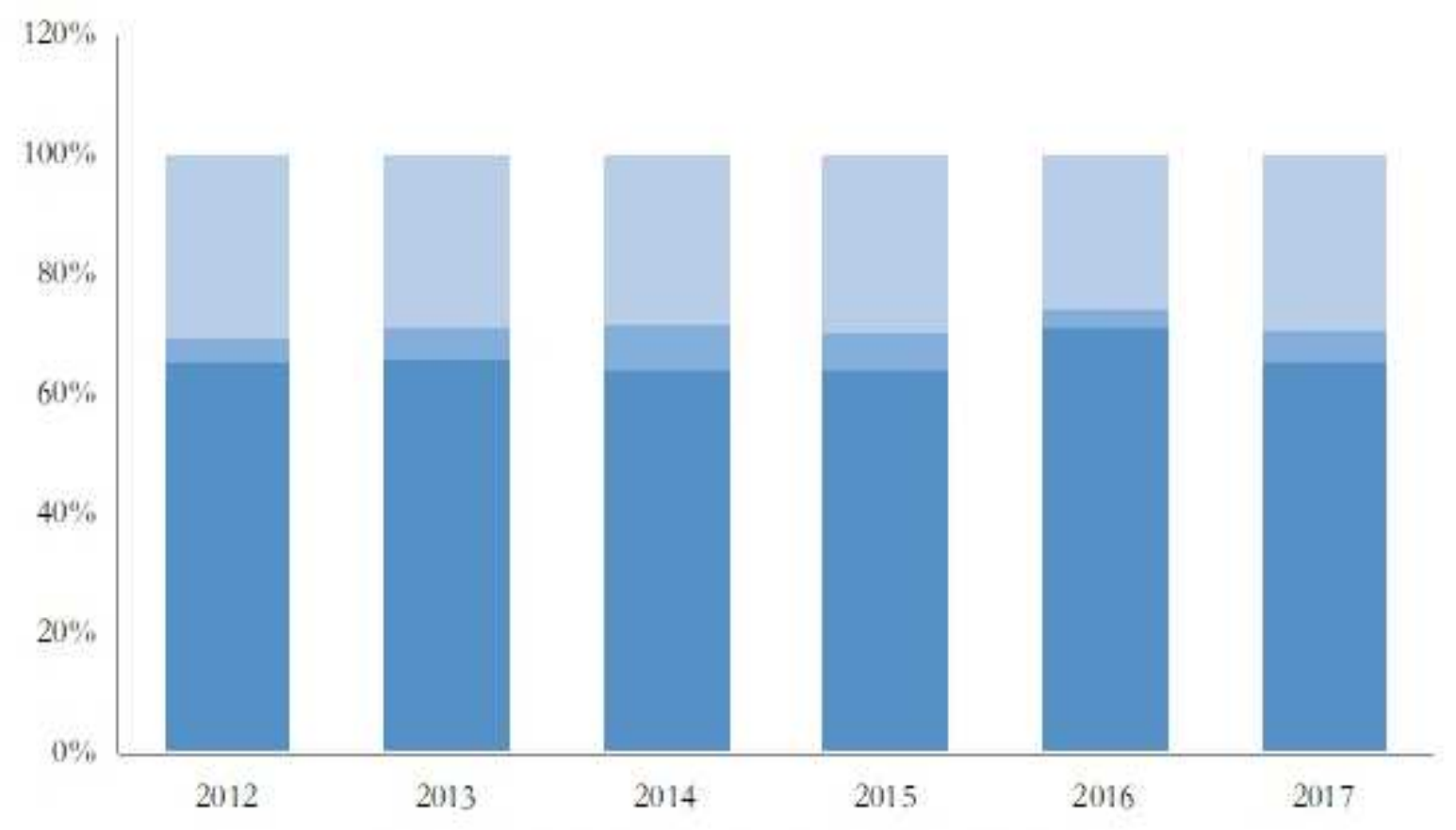




\subsection{Average Collection Period}

Figure 5 shows the information about the Average Collection Period ratio (ACP ratio) of five companies from the year 2011 until 2015. ACP ratio is an indicator of efficiency of the company take in days to collect its account receivables from the customers.

Before the overview trend analysis for both ratios on the above examined, the formula for those ratios from 2011- 2015 can be calculated as following: Average Collection Period Ratio: 365 Days x Account Receivables/ Credit Sales

\subsection{Average Collection Period Ratio}

Figure 5: Average Collection Period

The lower the ACP rate, the better because customers only need less than three It shows the effectiveness and efficiency of the month. Landmark company overall trend Corporate credit and collection policies. For this reason, this is a good fluctuation

In 2011, Expeditors International of Washington began collecting the minimum number of days for its accounts receivable

It takes less than a month to receive payment from their customers. result, Only 2.78 days. However, just like the time for the Perkad Landmark offers discounts Advance payments and fees for overdue payments based on the number of payment days. Receivables increase but only Expeditors International of Washington, average

The marginal changes from 2012 to 2017. The figure for the collection period of 2012 alone unfortunately took about three months to 25.81 days, but then surged to high customers to pay bills in 2015. 139.17 days (2012). Later in 2013, there were a number of factors that could affect the decline to 107.30 and a slight increase of 111.07, such as the unemployment rate (2014). The number of days customers paid in 2015 was high, with a value of 3.30, Expeditors International of Washington, which was 86.52, and the inflation rate was very low at 2.10 . The overall trend shows how ineffective this is. This means that the credit terms and collection policies of consumers with high unemployment rates have diminished, and so have companies. The customer spent a long time, the less the product's inflation rate and the time it took to repay the debt. For service, generate lower income. Therefore, the company's business and attracting investors, the customer's company can not repay the debt, it is important to be able to direct other companies to collect accounts in accordance with the policy. Because it can minimize various risks within five consecutive years and obtain YTLDExpeditors International of Washington shows investors trust to invest in the company. Good record in receiving payments from them 

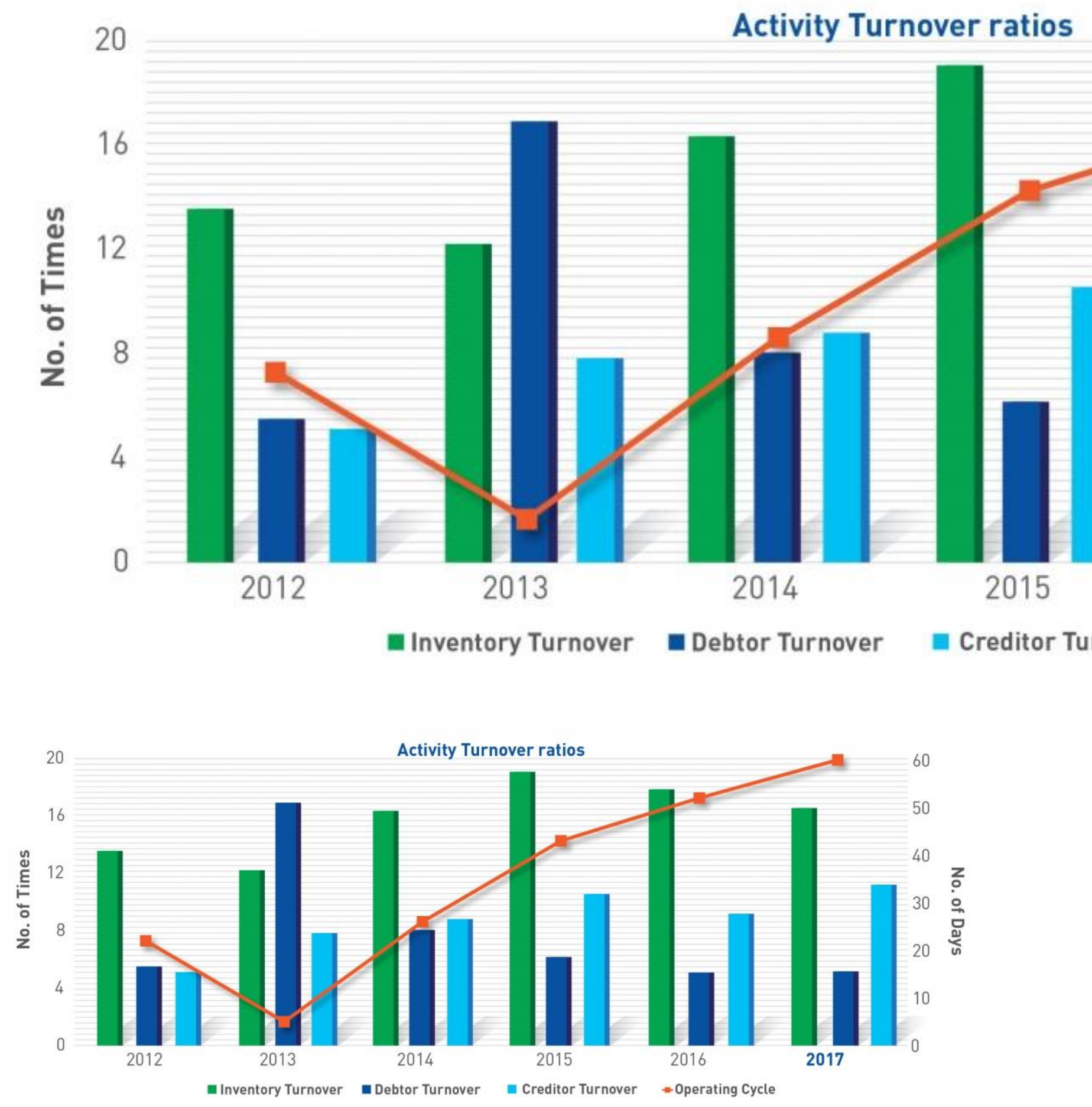


\subsection{Relationship of Return on Equity, Unemployment rate and Exchange rate to the Profitability}

According to the results of Pearson correlation output in Table 1, ROE and ROA have the strongest relationship, which is $88.3 \%$. P value $=0.00$. Table 2 explains the regression analysis and it can be observed that ROE is the most important variable. The beta value of the industry risk is 1.571 , which is higher than the market risk Beta $=1$. It indicates that it has higher risks and can bring higher profitability to the industry. The industry will change if the market's beta value changes by $1 \%$. The high volatility of stock prices and the attraction of risk recipient investors to invest in this Washington logistics company for high returns. However, at the end of 2015 , the company proved that it was the most volatile at this time compared to other years. Therefore, the table shows the high frequency of fluctuations throughout the five years.

$1.571 \%$ in the industry beta. The " $t$ " indicator also supports ROE as the main risk factor affecting profitability, with a maximum of 8.828. The regression results in Table 2 indicate that $\mathrm{ROE}$ has the most significant $\mathrm{P}$ value $=0.00$, compared to other variables. Ang (2001) supports this finding. He mentioned that if the ROE ratio increases, it will lead to profit expansion. Sawir (2005) has stated that in order to maximize the profit based on ROE, the investment strategy decided by the company needs to be used effectively. 
Table 1: Determinants of profitability of risk factors in the relevant matrix logistics industry

\begin{tabular}{|c|c|c|c|c|c|c|c|c|c|}
\hline \multicolumn{10}{|c|}{ Correlations } \\
\hline & & $\begin{array}{l}\text { Operati } \\
\text { onal } \\
\text { rato } \\
\end{array}$ & $\mathrm{ROA}$ & ROE & $\begin{array}{c}\text { Currrent } \\
\text { ratio }\end{array}$ & $\begin{array}{l}\text { Quick } \\
\text { ratio }\end{array}$ & $\begin{array}{l}\text { Average } \\
\text { collectio } \\
\mathrm{n} \text { period }\end{array}$ & $\begin{array}{l}\text { Debt to } \\
\text { income }\end{array}$ & $\begin{array}{l}\text { Operatin } \\
\text { g margin }\end{array}$ \\
\hline \multirow[t]{8}{*}{$\begin{array}{l}\text { Pearson } \\
\text { Correlation }\end{array}$} & $\begin{array}{l}\text { Operati } \\
\text { onal } \\
\text { ratio }\end{array}$ & 1.000 & -.918 & -.899 & .665 & .665 & -.174 & .955 & -.999 \\
\hline & ROA & -.918 & 1.000 & .996 & -.819 & -.819 & -.016 & -.972 & .905 \\
\hline & ROE & -.899 & .996 & 1.000 & -.867 & -.867 & .036 & -.948 & .884 \\
\hline & $\begin{array}{l}\text { Current } \\
\text { ratio }\end{array}$ & .665 & -.819 & -.867 & 1.000 & 1.000 & -.350 & .675 & -.639 \\
\hline & $\begin{array}{l}\text { Quick } \\
\text { ratio }\end{array}$ & .665 & -.819 & -.867 & 1.000 & 1.000 & -.350 & .675 & -.639 \\
\hline & $\begin{array}{l}\text { Averag } \\
\text { e } \\
\text { collecti } \\
\text { on } \\
\text { period }\end{array}$ & -.174 & -.016 & .036 & -.350 & -.350 & 1.000 & .078 & .170 \\
\hline & $\begin{array}{l}\text { Debit } \\
\text { to } \\
\text { income }\end{array}$ & .955 & -.972 & -.948 & .675 & .675 & .078 & 1.000 & -.950 \\
\hline & $\begin{array}{l}\text { Operati } \\
\text { ng } \\
\text { margin }\end{array}$ & -.999 & .905 & .884 & -.639 & -.639 & .170 & -.950 & 1.000 \\
\hline
\end{tabular}


Table 2: Coefficient Enter Method Regression analysis for Real Estate and Property Industry Risk Factors Determinants to Profitability

\section{Coefficients $^{\mathrm{a}}$}




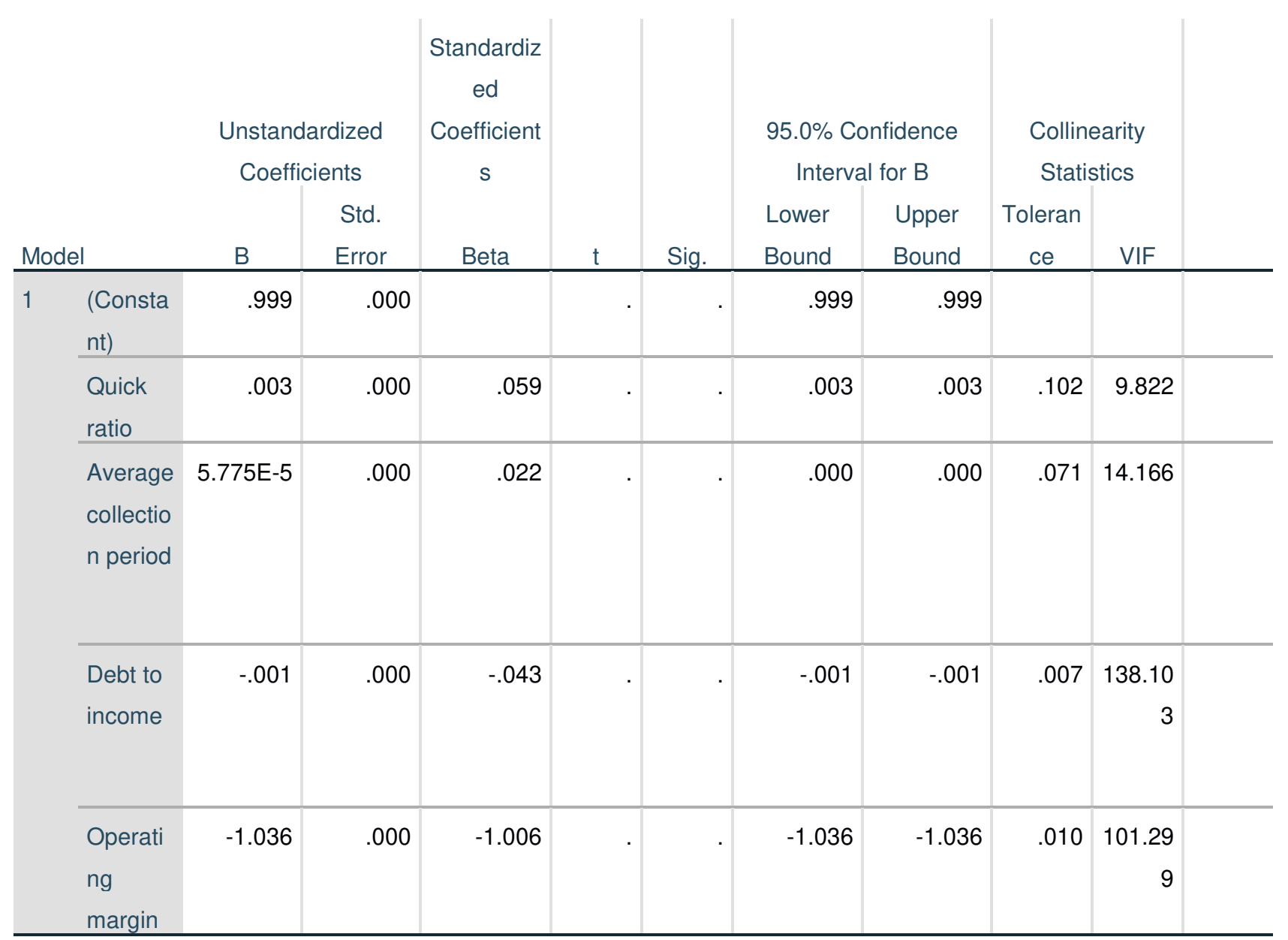

a. Dependent Variable: operational ratio

Table 3: Enter Regression Method Analysis for Real Estate and Property Industry Risk Factors Determinants to Profitability

\begin{tabular}{ll|l|l|l|r} 
& & \multicolumn{4}{c}{ Model Summary $^{\mathbf{b}}$} \\
Model & $\mathrm{R}$ & $\mathrm{R}$ Square & $\begin{array}{c}\text { Adjust R } \\
\text { Square }\end{array}$ & $\begin{array}{c}\text { Std. Error of the } \\
\text { Estimate }\end{array}$ & Durbin-Watson \\
\hline 1 & $1.000^{\mathrm{a}}$ & 1.000 & & & .333 \\
\hline
\end{tabular}

a. Predictors: (Constant), Quick ratio, Average collection period, Debt to income,

Operating margin

b. Dependent Variable: operating ratio

\section{9}

\begin{tabular}{|c|c|c|c|c|c|c|}
\hline \multicolumn{7}{|c|}{ ANOVA $^{a}$} \\
\hline Model & & Sum of Squares & $\mathrm{df}$ & Mean Square & $\mathrm{F}$ & Sig. \\
\hline \multirow[t]{3}{*}{1} & Regression & .000 & 4 & .000 & &. $\mathrm{~b}$ \\
\hline & Residual & .000 & 0 & & & \\
\hline & Total & .000 & 4 & & & \\
\hline
\end{tabular}

a. Dependent Variable: operational ratio

b. Predictors: (Constant), Quick ratio, Average collection period, Debt to income, Operating margin 


\subsection{Exchange rate to profitability}

There is a significant between profitability (ROA) and the exchange rate with a positive relationship with value of $\mathrm{P}=0.041>0.01$. The exchange rate on the other hand has a negative correlation towards profitability valued at $20.1 \%$. Based on the enter method used to run the data, the, the results shows a negative impact of $t=2.264$. The industry beta is 3.782 effecting negatively towards the market beta of 1 . As supported by Murrithi (2012) stated that there is a negative relationship between financial performance and currency exchange risk. Furthermore, the fluctuations of currency impact the revenues and expenses when it is derived or denominated in the foreign currency. This explains that currency risk factor gives a negative effect towards the ROA of the company where if the US dollars weakens the profitability of the company will reduce because there are also materials being imported from other countries for the construction purposes which might not be favorable to the Logistics company and development industry in US. Being said that exchange rate risk or currency is to be one of the systematic risk, it is difficult for the industry to mitigate risk since it of the industry control.

\subsection{DISCUSSION}

According to the overall five-year performance and development of Washington International Development Corporation, performance is favorable for 2012-2017. In terms of operating activities, profitability, assets and stock returns, the company's performance is more effective in commercial financial transactions. The risk factors involved in financial transactions include liquidity risks, operational risks other than changes in market prices, and internal and external factors. In addition, corporate performance may be affected by returns on equity, unemployment, and exchange rate risks.

\section{Recommendations:}

Investment of Shareholder equity risk: Return on equity (ROE) is used to measure efficiency of the company shareholder's fund to generate profits. Based on the regression result, Return on Equity (ROE) where $\mathrm{P}$ value $=0.00$, ROE ratio gives the most significant impact towards profitability. This strong significance relationship shows that the real estate and property can generate high returns. Furthermore, the company doesn't require to use too 
much of capital to be used for the operational activities. Hence, if the companies can give promising return to the investors, this can increase the reputation of the companies.

Unemployment Rate risk: From the regression and correlation result of unemployment rate where $\mathrm{P}$ value $>0.01$ with $99.97 \%$ confident, it shows there are positive

and significant relationship with unemployment that influence the profits of the company. The profitability of company are related to unemployment rate and may affect the company sustainability either for long-term or short-term. The relationship between the employment and profitability is essentially medium-term and related to changes in capital accumulation and income distribution. In case there is economic crisis,relationship between profitability and employment rate will be affected, if the profitability is decrease unemployment rate will increase this is because of the employment downsizing of the company is higher. Because of uncontrolled employment downsizing, unemployment rate would increase and profitability of company will be affected. Increasing in the unemployment rate is one of the external factors towards company and there is negative impact to the business financial transaction.

Exchange Rate risk: Based on the regression result, there is positive relationship between return on asset $(\mathrm{ROA})$ and the exchange rate where $\mathrm{P}$ value $=0.041>0.01$. Exchange rate is determined by economic factors as well which is the supply and demand, exchange rate is allowed to be verify with other currencies in financial transaction market. Other factors that influence the exchange rate are interest rates, economic growth, inflation rates and balance payment account. In aspect of foreign exchange market, there is specific quotation for the relative currency value unit in exchange transaction within countries.

ROE Profitability: The increase in the return on equity in business transactions indicates that the effectiveness of the company's management is indicative of the shareholders' investment capital. As a return on equity, the higher the ROE, the better the financial transaction, but if the ROE declines or declines, it will cause problems for the company. Therefore, investors will lose interest in investing in the company. The net value and equity of the profit of the company's shareholders in the entity area of the enterprise will be paid from the amount returned. From the investments that have already been made, the company will obtain profits from the shareholders' equity, and the profits can only make up for the probability loss. In addition, companies that can 
prevent huge losses can purchase insurance to protect the company from unexpected losses. For example, if the investment has no profit, the insurance policy will cover the loss.

Unemployment Rate of Commercial Companies: Unemployment rate is a measure of the labor force, which can be measured by the total number of employed and unemployed people in the work area. The factors leading to the unemployment rate will affect the stability of the company's financial transactions. In order to manage the unemployment rate, it can govern whether there are changes in government policies to reduce the restrictions on employment reductions or, in other words, have fixed interest rates. Through this method, the unemployment rate can be controlled. The policies that the economic sector emphasizes are macroeconomic policies and econometric models that help the company pay more attention to the medium-term development, and should consider the impact of income distribution on profitability.

Exchange rates in commercial transactions: The exchange rate currency will change with the time when the currency fluctuates. The currency's valuation can be determined through the inflow and outflow of currency. In order to reduce the possible losses in the future, the company can establish derivatives contracts based on currency exchange rates to reduce losses. For example, forward contracts protect exchange rate risk because most of the materials have been purchased from outside and involve intra-state import and export transactions. The forward contract function locks the price, the company will obtain the fixed transaction price in the transaction at the agreed currency exchange rate, and the company will avoid or minimize its loss. In addition, if the currency exchange between the two countries in the contract fluctuates, companies applying derivative contracts will not suffer losses because the company receives a fixed exchange rate. When purchasing in the future, the company will gain an advantage from the contract in this case.

\subsection{CONCLUSION}

In conclusion, external and internal factor are influenced the performances of Expeditors International of Washington that will affect the company profit. Overall performance of the company throughout the five years annual reports was showing that the Return on Equity (ROE), unemployment rate and exchange rate is most favorable to the profitability ratios. However, the ROA and ROE have influenced the most towards profitability of the company. The company 
should be able to manage the risk from internal and external factors with effective manner to generate high performance and gain profit. For performances of this company based on result of regression, correlation and ANOVA, ROE show the most significant when $\mathrm{p}=0.00$ and indicate it has higher impact on profitability follow by unemployment rate and exchange rate risk factor and this two external risk play important role in company to generate profit. It also cannot be control so company must do few things to reduce unemployment and exchange rate. For unemployment rate government must prepare policy to restrict number of staff to be removed during economic crisis. For exchange rate, the company must use derivative tool to mitigate the risk either to protect failure of the company and generate profit.

Companies that have a good and stable return on assets, return on equity, and return on investment show that the company has used resources efficiently and has effectively used management resources. Most risk taker investors are willing to bear the investment risk with lower expected returns. Typically, risk taker investors will invest in companies that have experienced volatile price changes over the five-year period. On the other hand, investors with unfavorable risks often invest in favorable ratio companies. Risk-neutral investors will choose to invest in companies with a minimum risk. Therefore, if the company has greater risks, the company can bring more profits to shareholders and the company's stakeholders.

\section{References}

J.B. Maverick, What are the major categories of financial risk for a company?12,February ,2018,from

https://www.investopedia.com/ask/answers/062415/what-are-major-categories-financial-riskcompany.asp

Bloomberg, May 14, 2018, Company Overview of Expeditors International of Washington, Inc,from

https://www.bloomberg.com/research/stocks/private/snapshot.asp?privcapId=270071

Profile, Returns, 2018, Expeditors International of Washington Inc (EXPD.O), from https://www.reuters.com/finance/stocks/companyProfile/EXPD.O J.Philippe, Value at Risk - The New Benchmark for Managing Financial Risk,17,July,2007,from book view,Philippe Jorion: Value at Risk - The New Benchmark for Managing Financial Risk: 3rd Edition, ISBN 0-07-146495-6, McGraw-Hill, 2007, 602 pages 